\title{
4E Advancement of Heat Recovery during Hot Seasons for a Building Integrated Photovoltaic Thermal (BIPV/T) System ${ }^{+}$
}

\author{
Ali Sohani ${ }^{1}\left(\mathbb{D}\right.$, Shayan Naderi ${ }^{2}$ and Gloria Pignatta ${ }^{2, *}$ (i) \\ 1 Lab of Optimization of Thermal Systems' Installations, Faculty of Mechanical Engineering-Energy Division, \\ K.N. Toosi University of Technology, P.O. Box 19395-1999, No. 15-19, Pardis Street, Mollasadra Avenue, \\ Vanak Square, Tehran 1999 143344, Iran; asohani@mail.kntu.ac.ir \\ 2 School of Built Environment, Faculty of Arts, Design, and Architecture, University of New South \\ Wales (UNSW), Sydney, NSW 2052, Australia; s.naderi@unsw.edu.au \\ * Correspondence: g.pignatta@unsw.edu.au \\ † Presented at the 3rd Built Environment Research Forum, Sydney, Australia, 1 December 2021.
}

Citation: Sohani, A.; Naderi, S.;

Pignatta, G. 4E Advancement of Heat Recovery during Hot Seasons for a Building Integrated Photovoltaic Thermal (BIPV/T) System. Environ. Sci. Proc. 2021, 12, 5. https:// doi.org/ 10.3390/environsciproc2021012005

Academic Editor: Luciano

Cardellicchio

Published: 15 December 2021

Publisher's Note: MDPI stays neutral with regard to jurisdictional claims in published maps and institutional affiliations.

Copyright: (c) 2021 by the authors. Licensee MDPI, Basel, Switzerland. This article is an open access article distributed under the terms and conditions of the Creative Commons Attribution (CC BY) license (https:// creativecommons.org/licenses/by/ $4.0 /)$.

\begin{abstract}
In conventional building integrated photovoltaic thermal (BIPV/T) systems, heat is only recovered during cold seasons. However, no recovery takes place in hot seasons. Therefore, this study comes up with an answer to the question "how much improvement in the amount of annual recovered heat (ANRH), average exergy efficiency (AAEE), and $\mathrm{CO}_{2}$ saving (ACDS), as well as payback period (PBP), is achieved when heat recovery is done in hot seasons?". These are representatives of energy, exergy, environmental and economic (4E) aspects, respectively. The results show a $135.6 \%, 1.8 \%$ and $123.0 \%$ enhancement in the ANRH, AAEE and ACDS, respectively, while PBP decreases from 6.10 to 3.94 years.
\end{abstract}

Keywords: 4E analysis; building integrated photovoltaic thermal (BIPV/T) system; comparative study; heat recovery enhancement; performance assessment; renewable energy; solar energy

\section{Introduction}

The wavelength of the incoming terrestrial solar radiation is in the range from 0.25 to $2.5 \mu \mathrm{m}$. Photovoltaic (PV) panels can only generate electricity from a proportion of the radiations in this range, which is close to the bandwidth of PV cells. The energy of the rest of the incoming radiation, which is said to be around $70 \%$ of the incoming radiation, dissipates to heat and increases the panel temperature. It has been reported that when panels work at higher temperatures, their efficiency is significantly lower. This is not favorable since the efficiency of PV panels drops in higher temperatures. This drop is about $0.5 \% \times\left({ }^{\circ} \mathrm{C}\right)^{-1}$ for temperatures above $25^{\circ} \mathrm{C}[1]$.

In buildings, the PV panels' generated heat can be removed from the panels and used in different applications. These technologies are called Building Integrated Photovoltaic Thermal (BIPV/T) systems. By removing heat from PV panels, their efficiency is significantly improved. Moreover, the collected heat can be used for space heating, ventilation and water heating, reducing the overall non-renewable energy consumption of the building. Some BIPV/T technologies are façade-based and are integrated into the façade, while some other types of BIPV/T are roof-based and are installed as a part of the roof. These technologies can replace the traditional construction materials, or they can be attached to them [2]. Absorbing the heat of PV panels can be conducted using the outdoor air, as the most common method simply uses an air gap behind the PV panels and wall.

Considering the increasing popularity of BIPV/T technologies, several studies have investigated them from different points of view. Table 1 provides a quick review of the most recent relevant ones. In this table, one item from the studies is also checked to make the novelty of this work clear. 
Table 1. A quick review of the most recent relevant studies.

\begin{tabular}{|c|c|c|c|}
\hline Study & Year & A Brief Description & $\begin{array}{l}\text { Was Heat Recovery during } \\
\text { Hot Seasons Considered? }\end{array}$ \\
\hline Zomer et al. [3] & 2020 & $\begin{array}{c}\text { Energy performance of a BIPV/T system with partial shading } \\
\text { was investigated. }\end{array}$ & No \\
\hline Spiliotis et al. [4] & 2020 & $\begin{array}{c}\text { Both DC and AC topologies for a BIPV/T system were } \\
\text { examined and compared. Energy and environmental criteria } \\
\text { were considered. }\end{array}$ & No \\
\hline Calise et al. [5] & 2020 & $\begin{array}{l}\text { A hybrid solar and wind driven system for integration to a } \\
\text { building was proposed and evaluated based on } \\
\text { thermoeconomic analysis. }\end{array}$ & No \\
\hline Saadon et al. [2] & 2021 & $\begin{array}{l}\text { Using semi-transparent PV panels for a BIPV/T was studied by } \\
\text { considering exergy, environmental and energy criteria. }\end{array}$ & No \\
\hline Tina et al. [6] & 2021 & $\begin{array}{c}\text { A number of technologies for a BIPV/T system were compared } \\
\text { together using energy-related factors. }\end{array}$ & No \\
\hline Lin et al. [7] & 2021 & $\begin{array}{l}\text { Multi-objective optimization was used to determine the best } \\
\text { design of a BIPV/T system. The objectives were from economic } \\
\text { and comfort aspects. }\end{array}$ & No \\
\hline Karthick et al. [8] & 2021 & $\begin{array}{l}\text { Using the eutectic mixture of phase-change (PCM) materials } \\
\text { was studied, where energy indicators were evaluated. }\end{array}$ & No \\
\hline Liu et al. [9] & 2021 & $\begin{array}{c}\text { Energy, environmental and economic issues were considered, } \\
\text { and the feasibility of employing BIPV / T systems for regions } \\
\text { with high solar radiation was evaluated. }\end{array}$ & No \\
\hline The current study & 2021 & $\begin{array}{l}\text { By considering } 4 \mathrm{E} \text { criteria, the enhancement of using heat } \\
\text { recovery in hot seasons is evaluated. }\end{array}$ & Yes \\
\hline
\end{tabular}

According to the information provided in Table 1, to the best of the authors' knowledge, in the previous studies, although PV heat is absorbed by PV panels during all seasons of the year, it has been only utilized during the cold seasons for applications such as space heating, and the hot air in hot seasons has been assumed to leave the system without any beneficial use. However, the air that absorbed the heat of PV panels could have potential uses for purposes such as desiccant regeneration, etc., in hot seasons. Therefore, this study was conducted to find the improvement of using annual heat recovery (AHR) instead of only winter heat recovery (WHR). This investigation was conducted in detail by evaluating the energy, exergy, environmental and economic (4E) criteria of the system.

\section{Materials and Methods}

In order to simulate the performance of a BIPV/T system, the modeling procedure utilized by Shahsavar and Rajabi [10] was employed. Since all the equations to obtain $4 \mathrm{E}$ criteria are found there, in order not to make this paper too lengthy, refer to that paper for more information.

A five-story residential building in Tehran, Iran, which was considered in a previous studies of the research team [11], was selected as the case study. Each story of that building has a $97.1 \mathrm{~m}^{2}$ floor area. A detailed description of the building, including the specifications and plans, can be found in [11].

The total area of installed PV panels is $45 \mathrm{~m}^{2}$ (15 m in height and $3 \mathrm{~m}$ in width). The PV panels are of the monocrystalline type, with a nominal efficiency of $15.5 \%$. Other specifications, including the thickness of layers, are available in the work conducted by Sohani et al. [12].

It is also worth mentioning that since the employed simulation method was previously validated, no more validation is required, and for that reason, the results section of this study does not contain that. In addition, the BIPV/T technology considered in this study was an active one, in which a fan was used for better heat transfer between the PV panels and the air stream. 


\section{Results}

Both the received solar radiation and ambient temperature in the hot season are higher than cold season. Consequently, PV panels have higher temperature levels in hot seasons, which means more heat is gained by the air flow stream. For that reason, by applying AHR instead of WHR, a considerable jump in the amount of recovered heat during a year is seen, as Figure 1a shows.

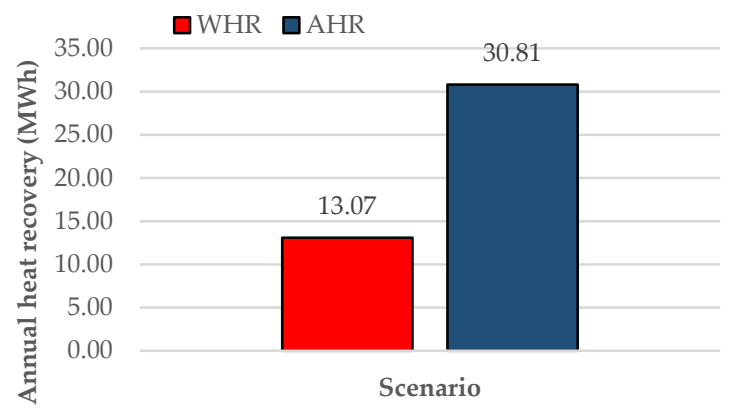

(a)

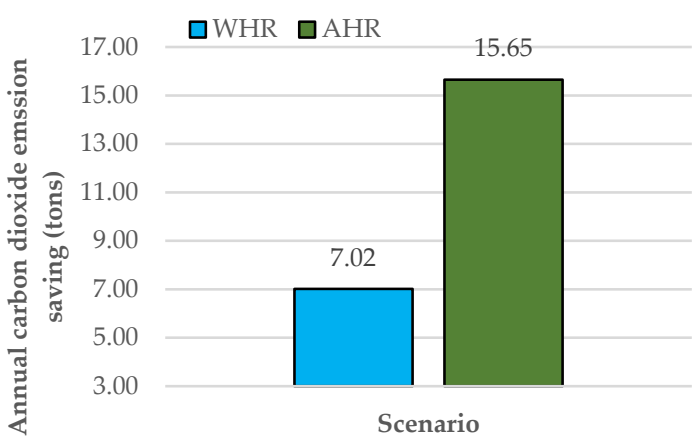

(c)

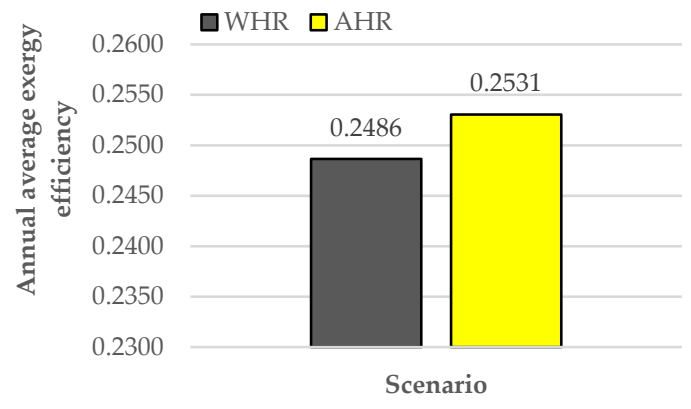

(b)

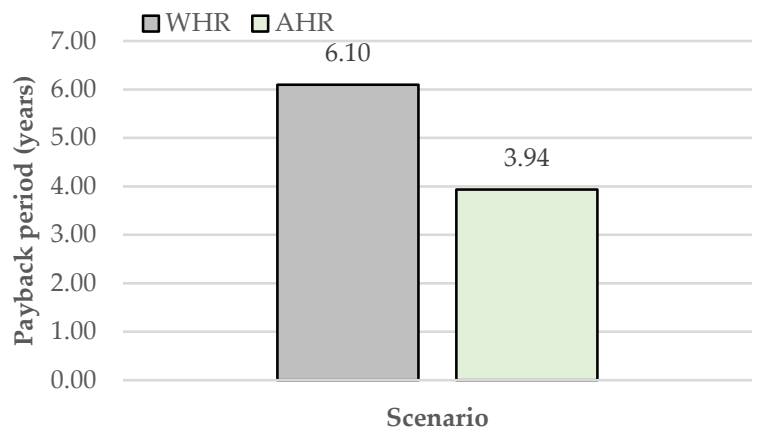

(d)

Figure 1. Comparing WHR and AHR scenarios; (a) ANRH; (b) AAEE; (c) ACDS; (d) PBP.

By taking advantage of WHR, 13.07 MWh of heat is recovered by the system. Nonetheless, using AHR is accompanied by the annual heat recovery of $30.81 \mathrm{MWh}$, which is $135.6 \%$ greater than WHR. Moreover, according to the data provided in Figure 1b, the AAEE increases from 0.2486 to 0.2531 , which indicates a $1.8 \%$ growth.

The increase in the AAEE is not as much as the heat recovered in a year. The reason is the main part of the exergy product of the system comes from the electricity produced, which is the same for both WHR and AHR. However, based on Figure 1c, the increase in the ACDS has the same order as the ANRH. This is because there is a direct relationship between the ACDS and the ANRH.

When WHR is utilized, 7.02 tons of $\mathrm{CO}_{2}$ is saved per annum. It experiences a $123.0 \%$ enhancement, where AHR can offer an ACDS of 15.65 tons. Additionally, the higher the amount of heat recovered by the system is, the lower the amount of natural gas purchased from the network should be. Purchasing lower amounts of natural gas leads to more money-saving and thus, a shorter PBP. Figure $1 \mathrm{~d}$ reveals that the PBP declines from 6.10 to 3.94 years, demonstrating a $35.4 \%$ improvement.

\section{Discussion}

The obtained results have proven that using a BIPV/T system in AHR mode has much higher benefits than the WHR scenario. This is not only limited to the energy aspect but also covers environmental and economic perspectives. Therefore, when a BIPV/T 
system runs in the AHR instead of WHR condition, it is more attractive for policymakers from different sides, as well as the investors and end-users. Moreover, the improvement strategy could be applied for both newly installed and in-operation BIPV / T systems, which shows its wide application range. Furthermore, it does not impose a considerable cost in contrast to other alternatives for the enhancement of BIPV/T technologies, such as using phase-change material (PCM), utilizing new generations of PV systems, etc. This could be taken into account as another significant advantage of using AHR. All the indicated points make running a system in AHR mode a very helpful strategy for the faster development of $\mathrm{BIPV} / \mathrm{T}$ technologies.

\section{Conclusions}

Using the potential of heat recovery in the hot seasons of a year led to a considerably better $4 \mathrm{E}$ performance for BIPV / T technology compared to heat recovery only in the winter seasons, which is conducted in conventional systems. Based on the significant achieved improvements in 4E criteria, in addition to being cheaply and easily applied for both design and retrofitting purposes, annual heat recovery has been strongly recommended for $\mathrm{BIPV} / \mathrm{T}$ systems instead of only winter heat recovery.

Author Contributions: Conceptualization, A.S., S.N. and G.P.; methodology, A.S.; software, A.S.; validation, A.S., S.N. and G.P.; formal analysis, A.S., S.N. and G.P.; investigation, A.S. and S.N.; resources, A.S., S.N. and G.P.; data curation, A.S. and S.N.; writing—original draft preparation, A.S.; writingreview and editing, S.N. and G.P.; visualization, A.S. and S.N.; project administration, S.N.; funding acquisition, G.P. All authors have read and agreed to the published version of the manuscript.

Funding: This research received no external funding.

Conflicts of Interest: The authors declare no conflict of interest.

\section{References}

1. Sathe, T.M.; Dhoble, A.S. A review on recent advancements in photovoltaic thermal techniques. Renew. Sustain. Energy Rev. 2017, 76, 645-672. [CrossRef]

2. Saadon, S.; Gaillard, L.; Menezo, C.; Giroux-Julien, S. Exergy, exergoeconomic and enviroeconomic analysis of a building integrated semi-transparent photovoltaic/thermal (BISTPV/T) by natural ventilation. Renew. Energy 2020, 150, 981-989. [CrossRef]

3. Zomer, C.; Custódio, I.; Antoniolli, A.; Rüther, R. Performance assessment of partially shaded building-integrated photovoltaic (BIPV) systems in a positive-energy solar energy laboratory building: Architecture perspectives. Sol. Energy 2020, 211, 879-896. [CrossRef]

4. Spiliotis, K.; Gonçalves, J.E.; Saelens, D.; Baert, K.; Driesen, J. Electrical system architectures for building-integrated photovoltaics: A comparative analysis using a modelling framework in Modelica. Appl. Energy 2020, 261, 114247. [CrossRef]

5. Calise, F.; Cappiello, F.L.; d'Accadia, M.D.; Vicidomini, M. Dynamic modelling and thermoeconomic analysis of micro wind turbines and building integrated photovoltaic panels. Renew. Energy 2020, 160, 633-652. [CrossRef]

6. Tina, G.M.; Scavo, F.B.; Aneli, S.; Gagliano, A. Assessment of the electrical and thermal performances of building integrated bifacial photovoltaic modules. J. Clean. Prod. 2021, 313, 127906. [CrossRef]

7. Lin, Y.; Zhong, S.; Yang, W.; Hao, X.; Li, C.-Q. Multi-objective design optimization on building integrated photovoltaic with Trombe wall and phase change material based on life cycle cost and thermal comfort. Sustain. Energy Technol. Assess. 2021, 46, 101277. [CrossRef]

8. Karthick, A.; Murugavel, K.K.; Ghosh, A.; Sudhakar, K.; Ramanan, P. Investigation of a binary eutectic mixture of phase change material for building integrated photovoltaic (BIPV) system. Sol. Energy Mater. Sol. Cells 2020, 207, 110360. [CrossRef]

9. Liu, Z.; Zhang, Y.; Yuan, X.; Liu, Y.; Xu, J.; Zhang, S.; He, B.-J. A comprehensive study of feasibility and applicability of building integrated photovoltaic (BIPV) systems in regions with high solar irradiance. J. Clean. Prod. 2021, 307, 127240. [CrossRef]

10. Shahsavar, A.; Rajabi, Y. Exergoeconomic and enviroeconomic study of an air based building integrated photovoltaic/thermal (BIPV/T) system. Energy 2018, 144, 877-886. [CrossRef]

11. Sohani, A.; Sayyaadi, H. Design and retrofit optimization of the cellulose evaporative cooling pad systems at diverse climatic conditions. Appl. Therm. Eng. 2017, 123, 1396-1418. [CrossRef]

12. Sohani, A.; Sayyaadi, H.; Doranehgard, M.H.; Nizetic, S.; Li, L.K.B. A method for improving the accuracy of numerical simulations of a photovoltaic panel. Sustain. Energy Technol. Assess. 2021, 47, 101433. [CrossRef] 